\title{
Earnings Management through Discretionary Expenditures in The U.S., Canada, and Asia
}

\author{
Namryoung Lee (Corresponding author) \\ Professor of Accounting, Korea Aerospace University \\ 200-1, Hwajeon-dong, Deokyang-gu, Goyang-city, Gyeonggi-do, Korea, 412-791 \\ Tel: 822-300-0093Ｅ-mail: nrlee@kau.ac.kr
}

Charles Swenson

Professor and Leventhal Research Fellow, Marshall School of Business

University of Southern California, 3660 Trousdale PKWY

University of Southern California, Los Angeles, CA 90089

Tel: 1-213-740-4854Ｅ-mail: cswenson@marshall.usc.edu

Received: September 24, 2010 Accepted: November 3, 2010 doi:10.5539/ibr.v4n2p257

\begin{abstract}
There is a considerable literature on U.S. companies' earnings management through discretionary accruals and real earnings management. We extend this literature to the international setting and include the effects of corporate tax on earnings management decisions. We find that US based models of earnings management work reasonably well in the Canadian setting, and except for the effects of taxes, in the Hong Kong, Japanese, Korean, and Taiwanese settings as well. We predict that firms' tax status may have a countervailing effect on such management. Consistent with this prediction, we find that firms with larger potential tax savings are more likely to use real earnings management to accelerate discretionary expenditures. Since these discretionary deductions have income-reducing effects for financial reporting purposes, the results suggest that income taxes have a strong incentive effect. However, this tax effect occurs for only U.S. and Canadian firms; Hong Kong, Japanese, Korean, and Taiwanese firms' discretionary accrual decisions appear to not be influenced by taxes. The results may have policy implications for other countries as well.
\end{abstract}

Keywords: Tax management, Discretionary expenditures, Discretionary accruals

\section{Introduction}

There is a considerable literature on U.S. companies' earnings management through discretionary accruals and real earnings management. We extend this literature to the international setting and also include the effects of corporate tax on earnings management decisions. Specifically, we examine discretionary spending for research and development (R\&D), selling and administrative expenses (SG\&A), and advertising. We find that US based models of earnings management work reasonably well in the Canadian setting as well, and except for the influence of taxes, work reasonably well for Hong Kong, Japanese, Korean, and Taiwanese firms as well.

For U.S. and Canadian firms, we find that firms with larger potential tax benefits are more likely to manage taxes through real expenditures management. Since these discretionary deductions have income-reducing expenses for financial reporting purposes, the results suggest that income taxes have a strong incentive effect in these two countries. In contrast, taxes appear to have no influence on Asia firms' discretionary expenditures. The results may have policy implications for other countries as well.

\section{Discretionary Real Expenditures}

Consider a situation where management decides whether to make additional discretionary real expenditures (DRE) in research and development (R\&D) selling, general, and administrative expenses (SG\&A), and advertising in period t. The decision is a function of the marginal return to such expenditures, or R (DRE), tax status (T) in t, cash flow constraints (CF), and financial reporting costs (FRC) of potentially missing earnings targets. Financial reporting costs are assumed to be increasing in $\mathrm{DRE}$, or $\mathrm{f}\left(\mathrm{DRE}_{\mathrm{t}}\right)$. Financial reporting costs are also a function of discretionary accruals made first; that is, the firm first makes necessary discretionary accruals (which have no tax 
effects in general) to exceed earnings target, there is little cost to making an income-decreasing discretionary accrual. After the firm makes the discretionary accrual decision, the firm decides on discretionary real expenditures.

The manager maximizes profit $\pi$ by solving spending on DRE in year $t$ :

$$
\operatorname{Max} \pi=\max \left[R\left(D R E_{t}\right)\left(1-T_{t}\right)-f\left(D R E_{t}\right)\right]
$$

s.t. $\mathrm{CF} \geq \mathrm{DRE}_{\mathrm{t}}$

Solving first order conditions, and rearranging:

$$
\partial \pi / \partial \mathrm{DRE}=\mathrm{R}\left(1-\mathrm{T}_{\mathrm{t}}\right) / \mathrm{f} .
$$

Thus, DRE is an increasing function of $\mathrm{R}$ and $\mathrm{T}$, a decreasing function of $\mathrm{f}$, and subject to cash flow considerations. In our data, we cannot observe $\mathrm{R}$, and assume it is constant across firms and time. However, we can proxy for financial reporting costs as follows:

Prediction 1: Ceteris paribus, firms' discretionary expenditures are lower when larger income-increasing discretionary accruals have been made.

We can proxy for cash flow considerations by proposing that growth firms can afford to make more discretionary expenditures, as follows:

Prediction 2: Ceteris paribus, firms' real earnings management through increased expenditures in years when the firm has increased sales and increased cash flows from operations.

Additionally, following from (2):

Prediction 3: Ceteris paribus, firms' real earnings management through increased expenditures is higher when marginal tax rates are higher.

Of course, in the international setting, marginal rates vary by country. For example, we would expect the tax effects to higher in the U.S. with a 35\% marginal rate, than in Hong Kong which has a $15 \%$ rate (on average).

There is a growing literature on real earnings management through discretionary expenditures, in the absence of tax considerations. The next section discusses that literature.

\section{Prior Research}

\subsection{Real Earnings Management}

Firms sometimes deliberately control earnings so that the figures hit a target and give information users "untruthful information". Schipper (1989) defined 'earnings management' as a purposeful intervention in the external financial reporting process, with the intent of obtaining some form of private gain. Healy and Wahlen (1999) note that "earnings management occurs when managers use judgment in financial reporting and in structuring transactions to alter financial reports to either mislead some stakeholders about the underlying economic performance of the company, or to influence contractual outcomes that depend on reported accounting numbers". In a review of the literature, Dechow and Skinner (2000) note that accruals management involves within-GAAP choices that try to "obscure" or "mask" true economic performance. They also indicate that methods such as acceleration of sales, and delaying of research and development and maintenance expenditures, can be used for earnings management purposes. Nelson et al. (2003) provide evidence how managers manage earnings based on the information obtained from survey of 253 experienced auditors. They afford the proof of earnings management involving revenue recognition, reserves and other accruals, and fixed asset impairment and amortization and so on.

Recently, real earnings management has become of interest to researchers. According to Graham et al.'s survey (2005), managers prefer earnings management using manipulation activities including reduction of discretionary expenditures or capital investments. Baber et al. (1991) and Bushee (1998) show that managers tend to reduce research and development expenditures to hit their earnings targets. Baber et al. find that relative R\&D spending is correlated managers' incentives to report positive or increasing income in the current period. Roychowdhury (2006) finds evidence that managers manipulate real activities to avoid reporting annual losses. His findings also show that managers use several real activities manipulation tools such as price discounts to temporarily increase sales, overproduction to report lower cost of goods sold, and reduction of discretionary expenditures for the purpose of improving reported margins.

Gunny (2005) finds that firms will use any one of the real earnings management strategies: reduction of R\&D; reduction of SG\&A; timing of income recognition from the disposal of long-lived assets and investments; and cutting prices to boost sales(and /or overproducing to decrease COGS expense). Also, he finds that real earnings management negatively affects subsequent operating performance in terms of low future earnings and cash flows. 
Zang (2006) reports on the evidence of the tradeoffs between accrual-based earnings management and real earnings management. She finds that firms decide first real earnings management and then accrual manipulation follows. She also provides evidence that both earnings management tools are correlated with the costs of accrual manipulation, and are negatively correlated with each other. Cohen et al. (2008) investigate earnings management across two main time periods-the pre-Sarbannes-Oxley (SOX) period and the post-SOX period. They find that firms are more prone to use real earnings management methods after the passage of SOX. The fact that real earnings management increased significantly after SOX is consistent with the evidence provided by Graham, Harvey, and Rajgopal (2005). They suggest that firms switched to managing earnings through real activities possibly because these methods are less likely to be revealed, although they are more costly.

More recently, Cohen and Zarowin (2008) study earnings management behavior around Seasoned Equity Offerings. They find that firms manage earnings through real activities manipulation as well through accruals and analyzed firms' tendency toward tradeoff real versus accrual-based earnings management activities around SEO's. They also find that the costs of real earnings management are apt to be greater than the costs of accrual-based earnings management, at least in the SEO context. Cohen and Zarowin (2008) also examine the relation between both real and accrual-based earnings management activities and firms' investment behavior. They find that firms managing earnings by either means overinvest in the years up to and including the period of high earnings management, and then underinvest, indicating that each type of earnings management is associated with significant real effects. Moreover, the excess investment associated with real earnings management is at least as great as the excess investment associated with accruals earnings management, and firms that engage in both real and accrual earnings management activities have greater investment effects than firms that engage in either one alone.

For a comprehensive review of the real earnings management literature, the reader is referred to $\mathrm{Xu}$, et al (2007).

\subsection{Earnings Management and Tax Avoidance}

While earnings management is primarily used to hit an earnings target, it can also be intended to obtain some other form of gain. Firms can trade off tax savings and meet their earnings target for financial reporting purposes by delaying discretionary expenditures. Alternatively, firms can reduce taxes by accelerating discretionary expenditures, but this may have an unfavorable effect if it causes the firm to miss earnings targets. Such dual objectives appear likely when firms determine the level of their book-tax conforming earnings management accounts such as R\&D, advertising, and SG\&A expenditures.

Lin (2006) reports that firms manage earnings for tax purposes. Examining Chinese firms which were about to lose their tax holiday benefits, i.e., experience a tax increase., Lin finds that in the year immediately before the tax rate increase, firms report discretionary accruals, on average, $1 \%$ higher than those in the years after tax rate increase. Badertscher et al. (2006) analyze the tax implications of pretax earnings management. They investigate the firm-specific characteristics that impact the choice between book-tax conforming earnings management and book-tax nonconforming earnings management strategies and find that 'nonconforming earnings management' is more prevalent than 'conforming earnings management'. Finally, Desai and Dharmapala (2006) examine the link between earnings management and corporate tax avoidance by illustrating how tax shelter products to make managers able to manipulate reported earnings.

\section{Data and Econometric Specification}

Assume that firms make earnings management decisions in the following order. First, they use discretionary accruals, which (because they have no cash flow implications) are considered to be less costly than discretionary expenditures. Next, they decide on discretionary expenditures. From an earnings management perspective, we expect a negative relationship between discretionary accruals and discretionary expenditures.

Our financial data is derived from Compustat Global for all U.S., Canadian, Hong Kong, Korean, Japanese, and Taiwanese firms from 1990-2007. We first estimate each firm's DACC (discretionary accruals), using the Jones model, modified by Kothari et al. (2005). Abnormal accruals are the residuals from modified Jones model regressions including ROA as shown in the following equation:

$$
\mathrm{TA}_{\mathrm{it}}=\alpha_{0}+\alpha_{1} / \mathrm{ASSETS}_{\mathrm{it}-1}+\alpha_{2} \Delta\left(\mathrm{SALES}_{\mathrm{it}}-\mathrm{AR}\right)+\alpha_{3} \mathrm{PPE}_{\mathrm{it}}+\alpha_{4} \mathrm{ROA}_{\mathrm{it}}+\varepsilon_{\mathrm{it}}
$$

where:

$T A_{i t}=$ as the change in non-cash current assets minus the change in current liabilities excluding the current portion of long-term debt minus depreciation and amortization, deflated by the beginning-of-year total assets;

$\operatorname{ASSETS~}_{i-1} \quad=$ the total assets at the beginning of fiscal year $\mathrm{t}$;

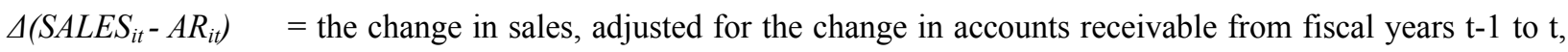


deflated by the beginning-of-year total assets;

$P P E_{i t} \quad=$ the gross property, plant and equipment at the end of fiscal year $\mathrm{t}$, deflated by the beginning-of-year total assets, and

$R O A_{i t} \quad=$ income before tax divided by lagged total assets of fiscal year $\mathrm{t}$.

COMPUSTAT Global data items for (3) are shown in Appendix 1.

To develop our proxies for real earnings management, we follow the method used by Roychowdhury (2006). We estimate normal discretionary expenses which include advertising expense, research and development, and SG\&A expenses using the following equation:

$$
\operatorname{DE}_{\mathrm{it}}=\beta_{0}+\beta_{1} / \operatorname{ASSETS}_{\mathrm{it}-1}+\beta_{2} \text { SALES }_{\mathrm{it}-1} / \operatorname{ASSETS}_{\mathrm{it}-1}+\varepsilon_{\mathrm{it}},
$$

where:

$D E_{i t} \quad=$ the sum of $\mathrm{R} \& \mathrm{D}$ expenses and Selling, General and Administrative expenses, deflated by the beginning-of-year total assets;

$A S S E T S_{i t-1}=$ the total assets at the beginning of fiscal year $\mathrm{t}$, and

SALES $_{\text {it- } /} /$ ASSETS $_{\text {it-1 }}=$ the sales of fiscal year $\mathrm{t}-1$, deflated by the beginning-of-year total assets.

Compustat data definitions for the above model are shown in Appendix 1. We next estimate abnormal discretionary accruals as actual accruals minus discretionary accruals from (4). Firm $i$ 's real earnings management (RM) via abnormal discretionary expenditures in year $t$ can be described as:

$$
\mathrm{RM}_{\mathrm{i}, \mathrm{t}}=\alpha+\sum_{\mathrm{t}=1}^{\mathrm{n}} \alpha_{\mathrm{t}} \mathrm{YR}_{\mathrm{t}}+\sum_{\mathrm{j}=1}^{\mathrm{n}} \beta_{\mathrm{j}} \mathrm{X}_{\mathrm{j}}+\delta \mathrm{T}_{\mathrm{t}, \mathrm{c}}+\varepsilon_{\mathrm{i}, \mathrm{t}}
$$

where $Y R$ is a fixed and estimable effect on real earnings management in any one year (which we later see to be increasing), $X$ is a vector of $R M$ factors common to all firms including year, industry membership, size (log of total assets and ROA), leverage, the amount of discretionary accruals the firm makes in year $t$ estimated from the residuals from (4), and cash flow constraints (change in sales and cash flows). Finally, change in GDP is used to control for country macro effects.

The model includes a tax variable, T, which is the firm's home country c's top statutory tax rate for year t. This variable is then multiplied by zero, 0.5, or 1, consistent with prior literature (Shevlin 1990; Graham 1996; Klassen and Mawani 2000; Pittman 2002). This variable is multiplied by zero if the firm has neither (a) current income tax expense nor (b) positive pre-tax income; 0.5 if the firm has either (a) or (b); and 1 if the firm has (a) and (b). Consistent with (2), we predict that increasing levels of this variable in any year will induce additional discretionary expenditures in that year if the tax benefits outweigh the cost to the firm in earnings objectives.

\section{Results}

\subsection{Descriptive Statistics}

Means and standard deviations for U.S., Canadian, Hong Kong, Japanese, Korean, and Taiwanese company data used in our subsequent regressions are reported in Table 1. Correlation coefficients for the same data are reported in Table 2. Compustat data definitions are reported in Appendix 1.

[Insert Tables 1 and 2 about here]

\subsection{Regression Results}

Because of many similarities between US and Canadian companies it is useful to first compare regressions on US based and Canadian based firms. Table 3 shows these regression results.

[Insert Table 3 about here]

Results are similar across the two countries. Model F statistics are all significant at 0.001 . The structural variables explaining discretionary expenditures have signs consistent with theory, and are all statistically significant. Firms with higher (lower) leverage seem to be more (less) likely to engage in earnings management using discretionary expenses. The relationship with the change in sales shows a positive relation as we expected; firms with more funds available are unlikely to decrease discretionary expenses. ROA is included to capture profitability; we find that profitable firms appear to have less incentive for earnings management by decreasing discretionary expenses with the predicted sign. Most importantly, we see a significant and negative relationship between discretionary accruals and discretionary expenditures, consistent with predictions. If firms can manage earnings sufficiently with accruals, they have relatively less need to manage earnings through discretionary expenditures. 
The coefficient estimates for discretionary accruals are larger for U.S. firms than for Canadian firms. Although both book and tax rules for SG\&A and advertising are the same in the U.S. and in Canada (expensing), the accounting rules for R\&D differ. While U.S. GAAP requires expensing of $R \& D$, Canada allows for capitalization and subsequent expensing. Thus for R\&D, Canadian firms have more opportunities to manage earnings though discretionary expensing or capitalization of R\&D.

Across the two countries, the tax variables are significant and consistent with predictions. In years when the firm experiences a higher statutory tax rate, it increases its discretionary expenses in the current year. The results are consistent with (2), and suggest that, after controlling for financial reporting objectives, firms tend to increase discretionary expenditures in higher tax rate years.

Regression results for Hong Kong, Japan, Korea, and Taiwan are shown in Table 4.

[Insert Table 4 about here]

The results (except for the tax rate variable) are similar to those for the U.S. and Canada. Except for Hong Kong companies, there is a significant negative relationship between discretionary accruals and discretionary real expenditures, supporting the conjecture of the substitute nature of the two earnings management techniques. All four countries' firms show significant and positive effects for ROA; as with U.S. and Canadian firms, these firms increase discretionary expenditures in years of higher profitability. Similarly, for all countries, discretionary expenditures increase in years of greater fund availability (increased sales). Unlike their U.S. and Canadian counterparts, East Asian firms do not show any evidence of creasing their discretionary expenditures in high tax rate years. As noted earlier, this was not unexpected for Japan (whose consistently high effective tax rates suggest that firms do not aggressively manage their taxes) and Hong Kong (where marginal rates are low, making some tax planning less important). On the other hand, we have no conjectures as to why tax rates are not significant for Korean and Taiwanese firms.

\section{Conclusion}

There is a considerable literature on US companies' earnings management through discretionary accruals and real expenditures management. We extend this literature to the international setting and include the effects of corporate tax on earnings management decisions, examining U.S., Canadian, Hong Kong, Japanese, Korean, and Taiwanese firms. We find that U.S. based models of earnings management (of discretionary expenses) work reasonably well in the international setting. We predict that firms' tax status may have a countervailing effect on such management. Consistent with this prediction, we find that U.S. and Canadian firms operating in higher tax rate years are more likely to use real earnings management to accelerate discretionary expenditures. Since these discretionary deductions have income-reducing expenses for financial reporting purposes, the results suggest that income taxes have a strong incentive effect. The results may also have policy implications. If countries raise statutory rates in a year, firms may react by accelerating expenses into that year. Such tax effects are not significant for East Asian firms, a finding for which we can explain only for Japanese and Hong Kong firms.

\section{References}

Baber, W., Fairfield, P. M. and Haggard, J. A. (1991). The effect of concern about reported income on discretionary spending decisions: the case of research and development. The Accounting Review 66 (4): 818-829.

Badertscher B., J. Phillips, M. Pincus, and S.Rego. (2006). Do Firms Manage Earnings Downward in a Book-Tax Conforming Manner? Working Paper, University of Connecticut, University of California - Irvine, and University of Iowa.

Barton, J. (2001). Does the use of financial derivatives affect earnings management decisions? The Accounting Review 76(1): 1-26.

Berger, P. (1993). Explicit and Implicit tax effects of the R\&D tax credit. Journal of Accounting Research 31 (2): 131-171.

Black, E. L., K. F. Sellers and T. S. Manly. (1998). Earnings management using asset sales: An international study of countries allowing noncurrent asset revaluation. Journal of Business Finance and Accounting 25(9/10): 1287-1319.

Bushee, B. (1998). The influence of institutional investors on myopic R\&D investment behavior. The Accounting Review 73 (3): 305-333.

Cohen, D., A. Dey, and T. Lys. (2008). Real and Accrual Based Earnings Management in the Pre and Post Sarbanes Oxley Periods. The Accounting Review 83: 757-787. 
Cohen, D. and P. Zarowin. (2008). Accrual-Based and Real Earnings Management Activities around Seasoned Equity Offerings. Working Paper. Stern School of Business, New York University.

Cohen, D. and P. Zarowin. (2008). Economic Consequences of Real and Accrual-Based Earnings Management Activities. Working Paper. Stern School of Business, New York University.

Dechow, P. M. and Skinner, D.J. (2000). Earnings management: Reconciling the views of accounting academics, practitioners, and regulators. Accounting Horizons 14 (June): 235-250.

Dechow, P.M., S. P. Kothari, and R. Watts. (1998). The Relation between Earnings and Cash Flows. Journal of Accounting and Economics 25: 133-168.

Desai, M., and D. Dharmapala. (2006). Corporate tax avoidance and high-powered incentives. Journal of Financial Economics 79: 145-179.

Graham, J. R. (1996). Proxies for the corporate marginal tax rate. Journal of Financial Economics 42 (2): 187-221.

Graham, J. R., C. R. Harvey, and S. Rajgopal. (2005). The Economic Implications of Corporate Financial Reporting. Journal of Accounting and Economics 40: 3-73.

Gunny, K. (2005). What are the Consequences of Real Earnings Management? Working Paper, University of Colorado.

Healy, P. and J. Wahlen. (1999). A Review of the Earnings Management Literature and its Implications for Standard Setting, Accounting Horizons: 365-384.

Huang, T., A. Lenk and A. Szezesny. (2006). Substitution, availability and preferences in earnings management: Empirical evidence from China. Working paper, Shandong Economic University, Johann Wolfgang Goethe University.

Klassen, K. J., and A. Mawani. (2000). The impact of financial and tax reporting incentives on option grants to Canadian CEOs. Contemporary Accounting Research 17 (2): 227-62.

Kothari, S. P., A. J. Leone, and C. Wasley. (2005). Performance Matched Discretionary Accrual Measures. Journal of Accounting and Economics 39: 163-197.

Lee, N. and C. Swenson. (2007). World-Wide Tax Avoidance. Working Paper, Leventhal School of Accounting, University of Southern California.

Lin, K. Z. (2006). The impact of tax holidays on earnings management: An empirical study of corporate reporting behavior in a developing-economy framework. The International Journal of Accounting 41: 63- 175

Lin, S., S. Radhakrishnan and L. N. Su. (2006). Earnings management and guidance for meeting or beating analysts' earnings forecasts. Working paper, California State University at Frenso, University of Texas and Hong Kong Polytechnic University.

Nelson, M. W., J. A. Elliott, and R. L. Tarpley. (2003). How are Earnings Managed? Accounting Horizons, Vol. 17(Supplement): 17-35.

Pittman, J. A. (2002). The influence of firm maturation on tax-induced financing and investment decisions. Journal of the American Taxation Association 24 (2): 35-59.

Roychowdhury, S. (2006). Earnings Management through Real Activities Manipulation. Journal of Accounting and Economics 42: 335-370.

Schipper, K. (1989). Earnings management. Accounting Horizons 3: 91-106.

Shevlin, T. J. (1990). Estimating corporate marginal tax rates with asymmetric tax treatment of gains and losses. Journal of the American Taxation Association 11 (2): 51-67.

Scholes, M., P. Wilson, and M. Wolfson. (1990). Tax planning, regulatory capital planning, and financial reporting strategy for commercial banks. The Review of Financial Studies 3 (4): 625-650.

Swenson, C. (1992). Some tests of the incentive effects of the research and experimentation tax credit. Journal of Public Economics 49: 203-218.

Wall Street Journal. (2008). Corporate-Tax Reporting Draws GAO Scrutiny.

Xu, R., Taylor, G., and M. Dugan. (2007). Review of Real Earnings Management Literature. Journal of Accounting Literature 26: 195-228. 
Zang, A. (2006). Evidence on the Tradeoff between Real Manipulation and Accrual Manipulation. Working Paper, University of Rochester

\section{Notes}

Note 1. For example, a recent Wall Street Journal article (Corporate-Tax Reporting Draws GAO Scrutiny by Jesse Drucker, August 13, 2008; Page A2) reported a GAO study which found that $23 \%$ of large U.S. corporations, and $70 \%$ of foreign corporations doing business in the U.S., do not pay federal income taxes in any given year. The GAO found that most U.S. corporations were wiping out their tax liability without using tax credits or net operating losses -- a mechanism that allows corporations to deduct from their taxable profits the losses generated in previous years. The most commonly used deductions were for salaries and wages and "other deductions."

Note 2. Harris (1993), Guenther (1994), Lopez et al. (1998), Maydew (1997), and Scholes, Wilson, and Wolfson (1990) prove that U.S. publicly held firms manage earnings in response to changes in corporate income tax-rates.

Note 3. Statutory tax rates were derived from Coopers and Lybrand (later, PwC) International Tax Summaries (various years) and from the OECD.

Note 4. Lin et al. (2006) prove that firms simultaneously use a comprehensive set of earnings management tools to meet or beat analyst earnings forecasts. Barton (2001) also demonstrates that firms smooth earnings by manipulating financing activities (financial derivatives) and accruals simultaneously. Meanwhile, it has been proved that managers prefer accruals management to manipulation via real business activities as accruals manipulation is less costly (Black et al. 1998; Huang et al. 2006). Also, real earnings management possibly gives negative impact on firms' future performances and firm value (Graham et al. 2005; Gunny 2005).

Note 5 . The total accruals can be obtained by subtracting operating cash flows from net income before extraordinary items and discontinued operations, or alternatively can be estimated as the change in non-cash current assets minus the change in current liabilities excluding the current portion of long-term debt minus depreciation and amortization. Due to limitations using cash flow statement items from Compustat Global, we define total accruals (TA) as the change in non-cash current assets minus the change in current liabilities excluding the current portion of long-term debt minus depreciation and amortization, scaled by lagged total assets.

Note 6. Roychowdhury (2006) generates the normal levels of CFO, discretionary expenses and production costs using the model the model developed by Dechow, Kothari and Watts (1998).

Note 7. With reference to COMPUSTAT Global data items, Disc (Data5+Data52)/lagged Data89; COMPUSTAT Global data does not provide a separate item for advertising expenses; as long as SG\&A is available, R\&D expenses are set to zero if they are missing.

Note 8 . When discretionary expenses are expressed as a function of current sales, significantly lower residuals can occur if firms increase reported earnings by managing sales upwards. Therefore, we model discretionary expenses as a function of lagged sales like Roychowdhury (2006) does.

Note 9. Because of the difficulty in obtaining reliable data, we do not include local taxes (e.g. taxes paid by U.S. firm to individual states).

Note 10. R\&D budgets are often based on sales (Berger 1993). Similarly, other prior studies suggest that R\&D investment depends on the availability of funds (Erikson and Jacobson 1992).

Note 11. Prior literature constructs a tax status variable that is equal to 1 if the firm has (a) no loss carryforwards and (b) positive pre-tax income; 0.5 if the firm has either (a) or (b); and 0 if the firm has neither (a) nor (b). Since Global Compustat does not report loss carryovers, we use current positive income tax expense as a proxy for absence of loss carryforwards.

Note 12. Absent from our explanatory variable is intangible assets, which can provide tax shields through amortization. Country accounting practices for intangibles vary so widely that inclusion of this variable created highly distortionary effects (which were not statistically significant) on all other variables.

Note 13. Random effects models were also tested, but diagnostics indicated fixed effects models (by year and industry) were a much better fit to the data. 
Table 1.Descriptive Statistics

\begin{tabular}{|c|c|c|c|c|c|c|c|c|}
\hline \multicolumn{9}{|l|}{ US firms } \\
\hline Variables & REM & Accruals & RDintensity & Leverage & $\triangle S A L E S$ & $R O A$ & SIZE & STR \\
\hline Mean & -0.0055 & -0.0257 & 0.3836 & 0.4856 & 0.1334 & -0.0102 & 5.8175 & 0.1510 \\
\hline Median & -0.0107 & -0.0266 & 0.0004 & 0.4935 & 0.0910 & 0.0466 & 5.7808 & 0.1750 \\
\hline Std. Deviation & 0.0294 & 0.0126 & 14.6145 & 0.2194 & 0.4086 & 0.5823 & 1.8624 & 0.0592 \\
\hline$Q 1$. & -0.0174 & -0.0307 & 0.0000 & 0.3128 & -0.0023 & -0.0057 & 4.5888 & 0.1700 \\
\hline Q3. & -0.0012 & -0.0216 & 0.0584 & 0.6452 & 0.2217 & 0.0978 & 7.0114 & 0.1750 \\
\hline \multicolumn{9}{|l|}{ Canadian firms } \\
\hline Variables & REM & Accruals & RDintensity & Leverage & $\triangle S A L E S$ & ROA & SIZE & STR \\
\hline Mean & -0.0146 & -0.0191 & 0.5047 & 0.4406 & 0.1829 & -0.0229 & 5.7036 & 0.1138 \\
\hline Median & -0.0202 & -0.0203 & 0.0000 & 0.4462 & 0.1195 & 0.0282 & 5.6936 & 0.1400 \\
\hline Std. Deviation & 0.0213 & 0.0200 & 12.7697 & 0.2136 & 0.5793 & 0.4777 & 1.7435 & 0.0452 \\
\hline$Q 1$. & -0.0227 & -0.0268 & 0.0000 & 0.2878 & -0.0156 & -0.0384 & 4.5704 & 0.1050 \\
\hline Q3. & -0.0135 & -0.0144 & 0.0042 & 0.5923 & 0.3257 & 0.0804 & 6.8821 & 0.1400 \\
\hline \multicolumn{9}{|l|}{ Korean firms } \\
\hline Variables & REM & Accruals & RDintensity & Leverage & $\triangle S A L E S$ & ROA & SIZE & STR \\
\hline Mean & -0.0173 & -0.0248 & 0.0675 & 0.5379 & -0.2210 & 0.0497 & 8.2575 & 0.1153 \\
\hline Median & -0.0153 & -0.0246 & 0.0031 & 0.5607 & 0.0899 & 0.0367 & 7.8201 & 0.1350 \\
\hline Std. Deviation & 0.0069 & 0.0089 & 1.6492 & 0.2133 & 1.5710 & 0.1028 & 2.1642 & 0.0455 \\
\hline$Q 1$. & -0.0215 & -0.0289 & 0.0001 & 0.3806 & -0.0156 & 0.0068 & 6.6169 & 0.1250 \\
\hline Q3. & -0.0153 & -0.0206 & 0.0169 & 0.6967 & 0.2161 & 0.0782 & 9.5950 & 0.1350 \\
\hline \multicolumn{9}{|l|}{ Japanese firms } \\
\hline Variables & REM & Accruals & RDintensity & Leverage & $\triangle S A L E S$ & $R O A$ & SIZE & STR \\
\hline Mean & -0.0235 & -0.0241 & 0.0173 & 0.5619 & -0.1316 & 0.0150 & 9.9773 & 0.1537 \\
\hline Median & -0.0159 & -0.0247 & 0.0027 & 0.5761 & 0.0232 & 0.0163 & 10.0886 & 0.1500 \\
\hline Std. Deviation & 0.0099 & 0.0072 & 0.1748 & 0.2160 & 0.6902 & 0.0849 & 1.5628 & 0.0143 \\
\hline$Q 1$. & -0.0190 & -0.0289 & 0.0000 & 0.4031 & -0.0374 & 0.0021 & 9.1421 & 0.1500 \\
\hline Q3. & -0.0113 & -0.0198 & 0.0184 & 0.7301 & 0.0888 & 0.0376 & 11.0344 & 0.1500 \\
\hline \multicolumn{9}{|c|}{ Taiwanese firms } \\
\hline Variables & $R E M$ & Accruals & RDintensity & Leverage & $\triangle S A L E S$ & $\mathrm{ROA}$ & SIZE & $S T R$ \\
\hline Mean & -0.0181 & -0.0252 & 0.0362 & 0.4604 & 0.1018 & 0.0575 & 8.4892 & 0.1102 \\
\hline Median & -0.0193 & -0.0257 & 0.0113 & 0.4671 & 0.1102 & 0.0489 & 8.3697 & 0.1250 \\
\hline Std. Deviation & 0.0050 & 0.0103 & 0.2289 & 0.1739 & 0.5347 & 0.1312 & 1.4356 & 0.0494 \\
\hline$Q 1$. & -0.0212 & -0.0298 & 0.0000 & 0.3389 & -0.0175 & 0.0049 & 7.4075 & 0.1250 \\
\hline Q3. & -0.0164 & -0.0211 & 0.0348 & 0.5845 & 0.2642 & 0.1054 & 9.3894 & 0.1250 \\
\hline \multicolumn{9}{|c|}{ HongKong firms } \\
\hline Variables & REM & Accruals & RDintensity & Leverage & $\triangle S A L E S$ & $R O A$ & SIZE & STR \\
\hline Mean & -0.0183 & -0.0258 & 0.0070 & 0.4092 & 0.0247 & 0.0517 & $7 . .2810$ & 0.0753 \\
\hline Median & -0.0205 & -0.0281 & 0.0000 & 0.3951 & 0.0630 & 0.0304 & 7.1712 & 0.0850 \\
\hline Std. Deviation & 0.0085 & 0.0336 & 0.0781 & 0.0450 & 0.6620 & 0.7499 & 1.8384 & 0.0282 \\
\hline$Q 1$. & -0.0226 & -0.0372 & 0.0000 & 0.2412 & -0.1269 & -0.0246 & 6.2284 & 0.0850 \\
\hline Q3. & -0.0171 & -0.0230 & 0.0000 & 0.5707 & 0.2305 & 0.0810 & 8.3397 & 0.0875 \\
\hline
\end{tabular}

Notes:

REM: Abnormal discretionary;

Accruals: Abnormal accruals;

R\&D Intensity: Data52/Data1;

Leverage: Total Liabilities/Total Assets $=($ Data89-Data135)/Data89;

$\triangle$ Sales: CSALES $=$ LN $($ data1 $)-\operatorname{LN}(\operatorname{lag}($ data1 $))$;

ROA: Profitability = pretax income/lagged total assets=Data21/lag(Data89);

SIZE: natural log of total assets(Data89), and

STR: Adjusted Statutory Tax Rate(STR), STR times Tax status. Consistent with prior literature, tax status is computed as 1 if the firm has (a) positive income tax expense and (b) positive pre-tax income; 0.5 if the firm has either (a) or (b); and 0 if the firm has neither (a) nor (b). 
Table 2. Correlations between Variables

\begin{tabular}{|c|c|c|c|c|c|c|c|c|c|}
\hline \multicolumn{10}{|c|}{ Canadian firms } \\
\hline \multirow{4}{*}{$\begin{array}{l}\text { US } \\
\text { firms }\end{array}$} & Variables & $R E M$ & Accruals & $\begin{array}{c}R \& D \\
\text { Intensity }\end{array}$ & Leverage & $\triangle S A L E S$ & $\mathrm{ROA}$ & SIZE & $S T R$ \\
\hline & REM & 1.0000 & -0.0268 & $0.1078^{*}$ & -0.0738 & $0.1383^{*}$ & $-0.6060 *$ & $-0.2307 *$ & $-0.1643 *$ \\
\hline & Accruals & $-0.0779 *$ & 1.0000 & -0.0229 & $0.0290 *$ & $0.1489^{*}$ & $-0.0678^{*}$ & $0.0878^{*}$ & $0.0424 *$ \\
\hline & $\begin{array}{c}R \& D \\
\text { Intensity }\end{array}$ & $0.1139 *$ & $-0.0216^{*}$ & 1.0000 & $-0.0490 *$ & $0.1660 *$ & $-0.0852 *$ & $-0.0497 *$ & $-0.0994 *$ \\
\hline & Leverage & $-0.1478^{*}$ & $0.1054^{*}$ & $-0.0303 *$ & 1.0000 & $-0.0368^{*}$ & $0.0407 *$ & $0.3573 *$ & $0.2540^{*}$ \\
\hline & $\triangle S A L E S$ & $0.2995 *$ & $-0.0655^{*}$ & $0.1997 *$ & $-0.0920 *$ & 1.0000 & 0.0139 & -0.0036 & 0.0100 \\
\hline & $\mathrm{ROA}$ & $-0.6020 *$ & $0.1234 *$ & $-0.1090 *$ & $0.0271 *$ & $-0.1599^{*}$ & 1.0000 & $0.2055^{*}$ & $0.3040^{*}$ \\
\hline & SIZE & $-0.1955^{*}$ & $0.0833^{*}$ & $-0.0302 *$ & $0.2983^{*}$ & $-0.0193^{*}$ & $0.1180 *$ & 1.0000 & $0.3528^{*}$ \\
\hline & STR & $-0.1501 *$ & $0.0421^{*}$ & $-0.0563 *$ & $0.0131 *$ & $0.0137^{*}$ & $0.2894 *$ & $0.2745^{*}$ & 1.0000 \\
\hline \multirow{10}{*}{$\begin{array}{l}\text { Korean } \\
\text { firms }\end{array}$} & \multicolumn{9}{|c|}{ Japanese firms } \\
\hline & Variables & $R E M$ & Accruals & $\begin{array}{c}R \& D \\
\text { Intensity }\end{array}$ & Leverage & $\triangle S A L E S$ & $R O A$ & SIZE & STR \\
\hline & $R E M$ & 1.0000 & $-0.1018^{*}$ & $0.0380^{*}$ & $-0.0942 *$ & $0.1507 *$ & $0.0606^{*}$ & $-0.1467^{*}$ & $-0.0697 *$ \\
\hline & Accruals & $-0.0549 *$ & 1.0000 & -0.0014 & $0.1047^{*}$ & $0.1212 *$ & $0.0410^{*}$ & $0.1168^{*}$ & $0.0195^{*}$ \\
\hline & $\begin{array}{c}R \& D \\
\text { Intensity }\end{array}$ & $-0.0549 *$ & -0.0071 & 1.0000 & $-0.0634 *$ & $0.0572 *$ & $-0.0288^{*}$ & -0.0084 & $-0.0582 *$ \\
\hline & Leverage & $-0.1347^{*}$ & 0.0480 & $-0.0591 *$ & 1.0000 & $-0.0500 *$ & $-0.1735^{*}$ & $0.0701 *$ & $0.1139 *$ \\
\hline & $\triangle S A L E S$ & $0.2315^{*}$ & $0.1948^{*}$ & $0.0957^{*}$ & $0.0764 *$ & 1.0000 & $0.0752^{*}$ & $0.2561 *$ & -0.0042 \\
\hline & ROA & $0.2498^{*}$ & -0.0144 & -0.0326 & $-0.2782 *$ & $0.1518^{*}$ & 1.0000 & $0.0387^{*}$ & $0.0412 *$ \\
\hline & SIZE & $0.0550^{*}$ & $0.0652 *$ & -0.0010 & 0.0135 & $0.3217^{*}$ & $0.2200^{*}$ & 1.0000 & $0.0926^{*}$ \\
\hline & STR & $0.1071 *$ & $0.0813^{*}$ & $-0.1228^{*}$ & $-0.0883^{*}$ & $0.1627^{*}$ & $0.4463^{*}$ & $0.1118^{*}$ & 1.0000 \\
\hline
\end{tabular}

\begin{tabular}{|c|c|c|c|c|c|c|c|c|c|}
\hline & \multicolumn{9}{|c|}{ Taiwanese firms } \\
\hline \multirow{9}{*}{$\begin{array}{l}\text { Hong } \\
\text {-Kong firms }\end{array}$} & Variables & REM & Accruals & $\begin{array}{c}R \& D \\
\text { Intensity }\end{array}$ & Leverage & $\triangle S A L E S$ & $R O A$ & SIZE & STR \\
\hline & REM & 1.0000 & $-0.1005^{*}$ & $0.0793 *$ & $-0.0704 *$ & $0.1360 *$ & $0.2228 *$ & $-0.2802 *$ & $0.0996^{*}$ \\
\hline & Accruals & $0.1982 *$ & 1.0000 & 0.0048 & -0.0185 & $0.1206^{*}$ & $0.3253^{*}$ & $0.1055^{*}$ & 0.0027 \\
\hline & $\begin{array}{c}R \& D \\
\text { Intensity }\end{array}$ & 0.0242 & -0.0168 & 1.0000 & $-0.0810^{*}$ & $0.1588 *$ & -0.0061 & $-0.0541 *$ & $-0.0631 *$ \\
\hline & Leverage & 0.0457 & -0.0371 & 0.0470 & 1.0000 & -0.0226 & $-0.3392 *$ & $0.2474 *$ & $-0.1965^{*}$ \\
\hline & $\triangle S A L E S$ & $0.0974 *$ & -0.0364 & $0.1531 *$ & 0.1114* & 1.0000 & $0.2977 *$ & $0.1663^{*}$ & $0.1343^{*}$ \\
\hline & $R O A$ & $0.0908^{*}$ & $0.8755^{*}$ & -0.0237 & $-0.0859 *$ & -0.0174 & 1.0000 & $0.0360^{*}$ & $0.3699 *$ \\
\hline & SIZE & $-0.1791 *$ & -0.0374 & $-0.0732 *$ & 0.1034* & $0.0730 *$ & 0.0387 & 1.0000 & 0.0129 \\
\hline & STR & -0.0260 & 0.0107 & $-0.1622 *$ & 0.0303 & 0.0336 & $0.1359 *$ & $0.3631 *$ & 1.0000 \\
\hline
\end{tabular}

Notes:

REM: Abnormal discretionary;

Accruals: Abnormal accruals;

IS: $\{($ Data21+Data5+Data52) $-\operatorname{lag}($ Data5+Data52) $\} / \operatorname{lag}$ (Data89);

R\&D Intensity: Data52/Data1;

Leverage: Total Liabilities/Total Assets $=($ Data89-Data135 $) /$ Data89;

$\triangle$ Sales: CSALES $=$ LN (data1 $)-\operatorname{LN}(\operatorname{lag}($ data1 $))$;

ROA: Profitability = pretax income/lagged total assets=Data21/lag(Data89);

SIZE: natural log of total assets(Data89);

Ch_GDP: Change in GDP, and

STR: Adjusted Statutory Tax Rate(STR), STR times Tax status. Consistent with prior literature, tax status is computed as 1 if the firm has (a) positive income tax expense and (b) positive pre-tax income; 0.5 if the firm has either (a) or (b); and 0 if the firm has neither (a) nor (b).

*Correlation is significant at the 0.05 level. 
Table 3. Factors Affecting Real Earnings Management: Discretionary Expenditures 1990-2007

$(t$ - statistics in parentheses, coefficients rounded)

Model: $R E M_{i, t}=\alpha_{0}+\beta_{1}$ Accruals $+\beta_{2}$ RDintensity $+\beta_{3}$ Leverage $+\beta_{4} 4$ Sales $+\beta_{5} R O A+\beta_{6}$ SIZE $+\beta_{7}$ Tax + Year

Dummies + Industry Dummies $+\varepsilon_{i, t}$

Panel A: US and Canadian Firms

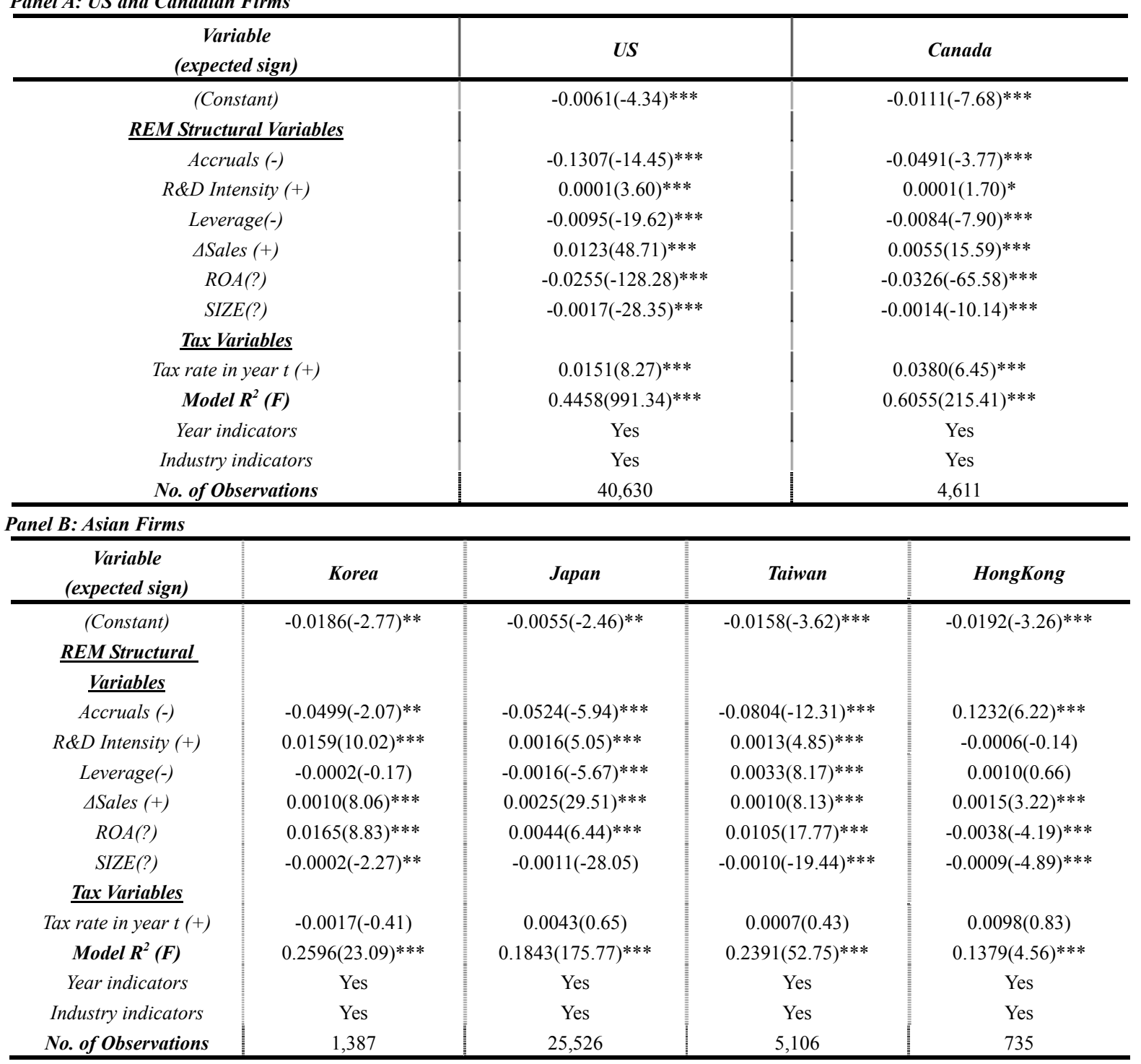

Notes:

*** Significant at 0.01 level

** Significant at 0.05 level

* Significant at 0.1 level

REM: Abnormal discretionary;

Accruals: Abnormal accruals;

R\&D Intensity: Data52/Data1;

Leverage: Total Liabilities/Total Assets= (Data89-Data135)/Data89;

$\triangle$ Sales: CSALES $=$ LN(data1) $-\operatorname{LN}(\operatorname{lag}($ data1 $))$;

ROA: Profitability = pretax income/lagged total assets=Data21/lag(Data89);

SIZE: natural log of total assets(Data89); and

STR: Adjusted Statutory Tax Rate(STR), STR times Tax status. Consistent with prior literature, tax status is computed as 1 if the firm has (a) positive income tax expense and (b) positive pre-tax income; 0.5 if the firm has either (a) or (b); and 0 if the firm has neither (a) nor (b). 